\title{
Identifying the Ozone Weekend Effect in the air quality of the northern Andean region of Ecuador
}

\author{
R. Parra \& E. Franco \\ Instituto de Investigaciones Atmosféricas, \\ Colegio de Ciencias e Ingeniería, \\ Universidad San Francisco de Quito, Ecuador
}

\begin{abstract}
The Weekend Effect (WE) is a phenomenon that occurs in some urban areas, characterized by increased concentrations of $\mathrm{O}_{3}$ and decreased emissions of its precursors $\left(\mathrm{NO}_{\mathrm{x}}\right.$ and $\left.\mathrm{VOC}\right)$ during weekend days, in comparison to weekdays. The study of the WE is relevant for understanding the behavior of pollutants; and hence, for air quality control. We analyzed the hourly records of the period 20052012, from 8 stations of the air quality network from the Distrito Metropolitano de Quito (northern Andean region of Ecuador). Both for each station and year, 3 mean-daily profiles were obtained for $\mathrm{CO}, \mathrm{NO}_{2}, \mathrm{PM}_{2.5}$ and $\mathrm{O}_{3}$, corresponding to weekdays, Saturdays and Sundays. The $\mathrm{CO}, \mathrm{NO}_{2}$ and $\mathrm{PM}_{2.5}$ profiles from Centro (historic center of Quito) and Belisario (center-north) stations, declined on Sundays. However the $\mathrm{O}_{3}$ profiles were higher on Saturdays and Sundays. The $\mathrm{O}_{3}$ 8-h mean concentrations of Sundays were higher in Belisario (19.7-31.1\%) and Centro (11.7-18.4\%), in comparison to weekdays. These results indicate the presence of the WE around these 2 stations, which probably are located in a VOClimited region for photochemical $\mathrm{O}_{3}$ production.

Keywords: Distrito Metropolitano de Quito, VOC-Limited Regime, $N_{x}$-Limited Regime.
\end{abstract}

\section{Introduction}

Tropospheric ozone $\left(\mathrm{O}_{3}\right)$ is a secondary air pollutant produced from the photochemical interaction of nitrogen oxides $\left(\mathrm{NO}_{\mathrm{x}}=\mathrm{NO}\right.$ (nitric oxide) $+\mathrm{NO}_{2}$ 
(nitrogen dioxide)) and volatile organic compounds (VOC), through a complex set of chemical reactions under the influence of solar radiation.

In the background troposphere, $\mathrm{O}_{3}$ concentration is determined by the following reactions [1]:

$$
\begin{gathered}
\mathrm{NO}_{2}+\text { solar radiation } \rightarrow \mathrm{NO}+\mathrm{O} \\
\mathrm{O}+\mathrm{O}_{2} \rightarrow \mathrm{O}_{3} \\
\mathrm{NO}+\mathrm{O}_{3} \rightarrow \mathrm{NO}_{2}+\mathrm{O}_{2}
\end{gathered}
$$

$\mathrm{NO}_{2}$ is broken by solar radiation into $\mathrm{NO}$ and $\mathrm{O}$ (Eq. (1)). The resulting molecule of $\mathrm{O}$ then combines with $\mathrm{O}_{2}$, forming $\mathrm{O}_{3}$ (Eq. (2)). In absence of VOC, the $\mathrm{O}_{3}$ of reaction (2) combines with $\mathrm{NO}$, regenerating $\mathrm{NO}_{2}$ and $\mathrm{O}_{2}$ (Eq. (3)). When VOC emissions happen, they are oxidized to free radicals $\left(\mathrm{RO}_{2}{ }^{*}\right)$ which react with $\mathrm{NO}$, producing $\mathrm{NO}_{2}$ (Eq. (4)) without the consumption, and as a consequence, promoting the accumulation of $\mathrm{O}_{3}$.

$$
\mathrm{RO}_{2}{ }^{*}+\mathrm{NO} \rightarrow \mathrm{NO}_{2}+\mathrm{RO}^{*}
$$

The relationship between $\mathrm{O}_{3}, \mathrm{NO}_{\mathrm{x}}$ and $\mathrm{VOC}$ is complex. Fig. 1 shows a plot of $\mathrm{O}_{3}$ concentrations resulting from different initial mixtures of $\mathrm{NO}_{x}$ and VOC. $\mathrm{NO}_{x}$ emissions promote $\mathrm{O}_{3}$ formation when VOC are abundant, but restrict or even reduce $\mathrm{O}_{3}$ formation when VOC are scarce. In a given air parcel, the relative balance of $\mathrm{VOC}$ and $\mathrm{NO}_{\mathrm{x}}$ (expressed in terms of the $\mathrm{VOC} / \mathrm{NO}_{\mathrm{x}}$ ratio) determines whether the available $\mathrm{NO}_{x}$ behaves as a net $\mathrm{O}_{3}$ generator or a net $\mathrm{O}_{3}$ inhibitor [2]. When the $\mathrm{VOC} / \mathrm{NO}_{\mathrm{x}}$ ratio is high ( 8 or higher), the amount of $\mathrm{NO}_{\mathrm{x}}$ tends to limit the $\mathrm{O}_{3}$ formation $\left(\mathrm{NO}_{\mathrm{x}}\right.$-Limited Regime of Fig. 1). When the $\mathrm{VOC} / \mathrm{NO}_{\mathrm{x}}$ ratio is low ( 8 or lower), the amount of VOC tends to limit the $\mathrm{O}_{3}$ production (VOCLimited Regime of Fig. 1). Because of the nature of VOC and $\mathrm{NO}_{\mathrm{x}}$ emissions in urban zones, air parcels exposed to these emissions are initially within the VOCLimited Regime [4].

A further complication of $\mathrm{O}_{3}$ behavior arises from the transport, dispersion, dilution and photochemical reactions into air parcels.

In the frame of this complexity, the Weekend Effect (WE) is a phenomenon that occurs in some urban areas, characterized by increased concentrations of $\mathrm{O}_{3}$ during weekends, although the emissions of $\mathrm{NO}_{\mathrm{x}}$ and $\mathrm{VOC}$ are typically lower, in comparison to weekdays.

The WE was first reported in the United States in the 1970s $[5,6]$ and has since been reported mainly in the U.S. and Europe [7-10]. The CARB studied the WE in California, and seven hypotheses were been set for this area [2]:

1st NOx reduction: the lower levels of on-road traffic during weekends promote the formation of $\mathrm{O}_{3}$, because the reduction of $\mathrm{NO}_{\mathrm{x}}$ emission in a VOC-Limited Regime (Fig. 1).

2nd $\mathrm{NO}_{\mathrm{x}}$ timing: during the morning, $\mathrm{NO}_{\mathrm{x}}$ emissions are delayed on weekends, reaching a more active photochemical system, and as consequence, producing $\mathrm{O}_{3}$ more efficiently; in comparison to $\mathrm{NO}_{\mathrm{x}}$ emitted on weekdays. 


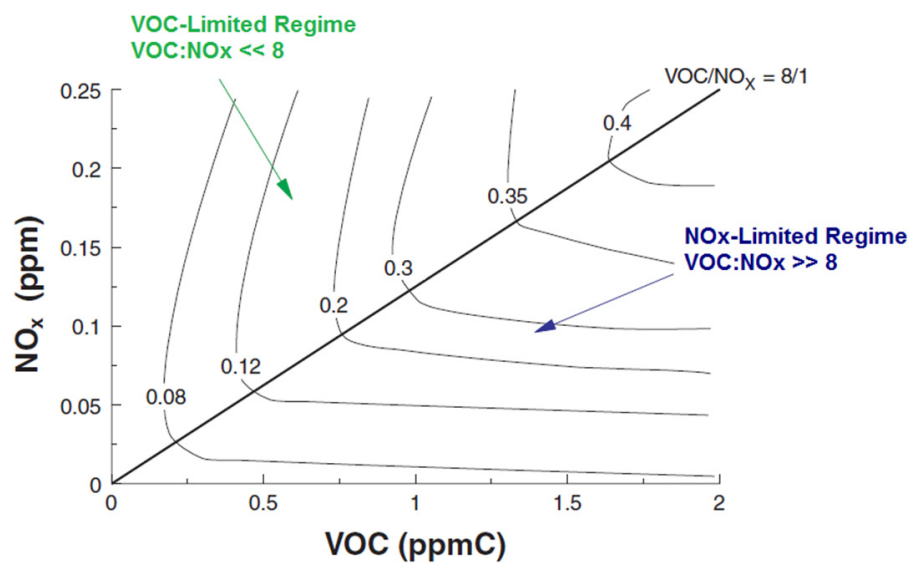

Figure 1: Isopleths of 1-h maximum $\mathrm{O}_{3}$ concentrations (ppm) calculated as a function of initial VOC and $\mathrm{NO}_{\mathrm{x}}$ concentrations and the regions of the diagram that are characterized by VOC- or $\mathrm{NO}_{\mathrm{x}}$-limitation. Adapted from NRC [3].

3rd carryover near the ground level: more $\mathrm{O}_{3}$ is formed on weekends because extra emissions from increased traffic on Friday and Saturday nights participate in O3 production during the daylight hours that follow.

4th carryover aloft: the reservoir of pollutants-which can be rich in $\mathrm{O}_{3}$ and other pollutants-that carries over from one day to the next above the nocturnal boundary layer may exert a greater influence on surface $\mathrm{O}_{3}$ concentrations on weekends than on weekdays.

5th increased weekend emissions: more $\mathrm{O}_{3}$ is produced because there are more $\mathrm{NO}_{\mathrm{x}}$ and VOC emissions on weekends.

6th aerosols and ultraviolet radiation (UV): the amount of soot (elemental carbon) and other particles is greater on weekdays than weekends. As soot absorbs $\mathrm{UV}$, the lower concentration of soot during weekends absorbs less UV, allowing more photochemical activity that increases $\mathrm{O}_{3}$ formation.

7th surface $\mathrm{O}_{3}$ quenching: less $\mathrm{O}_{3}$ is destroyed on weekends because the reduced $\mathrm{NO}_{\mathrm{x}}$ emissions.

The study and the assessment of the contribution of these hypothesis behind the WE are relevant for understanding the behavior of pollutants, and hence for air quality control. As a first step in this direction, we analyzed the air quality data from the Distrito Metropolitano de Quito (DMQ) (northern Andean region of Ecuador) to identify the occurrence of the WE in this region. The DMQ is located near the Equator (Fig. 2). It has a complex topography, with heights between 800 and 4000 masl.

The air quality network from the DMQ was installed during 2003. The network is equipped with automatic stations to measure in real time the concentrations of carbon monoxide $(\mathrm{CO})$, sulfur dioxide $\left(\mathrm{SO}_{2}\right)$, fine particulate matter $\left(\mathrm{PM}_{2.5}\right), \mathrm{NO}_{2}$ and $\mathrm{O}_{3}$. It provides official information since 2004. 


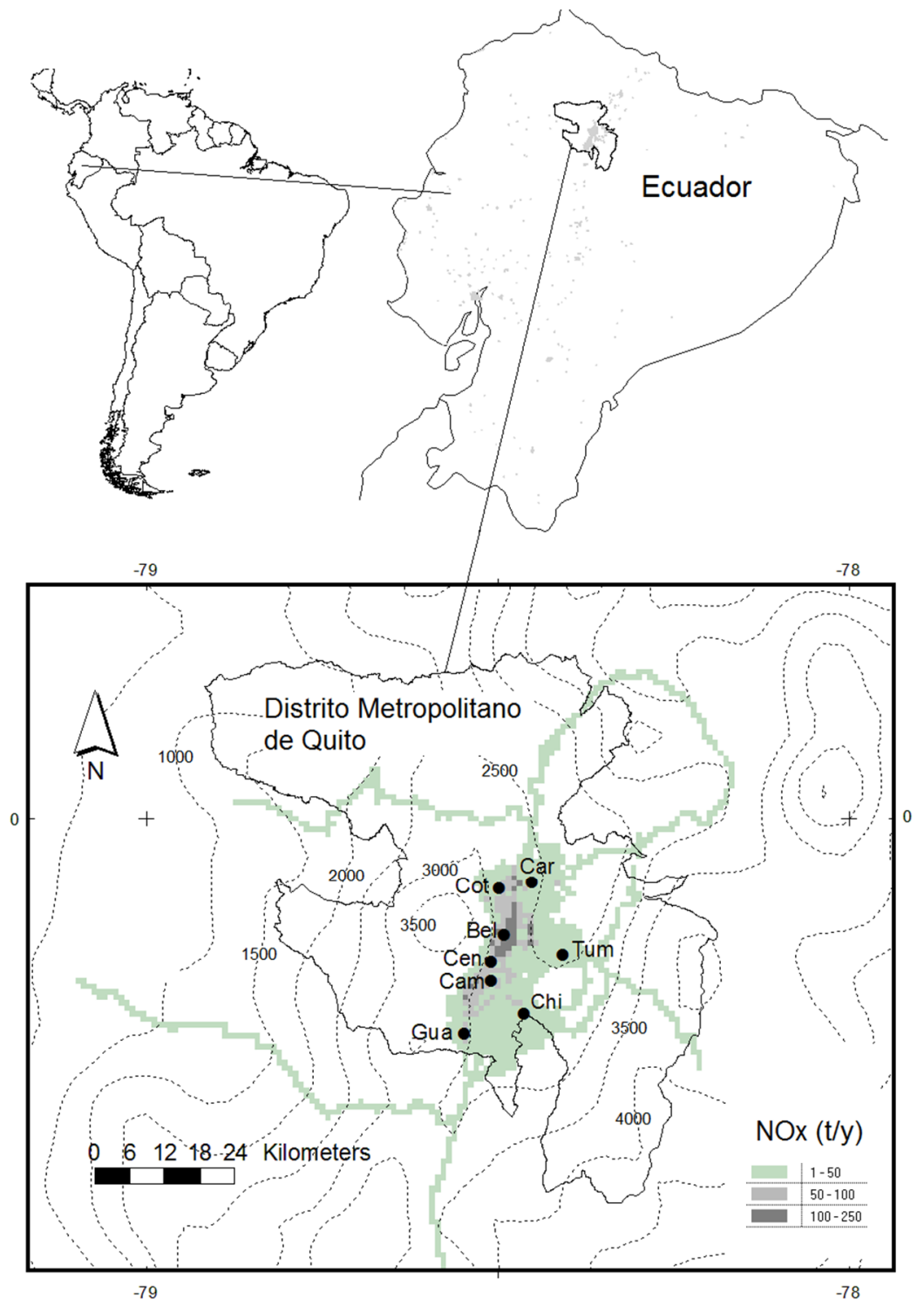

Figure 2: Location of the Distrito Metropolitano de Quito and of the 8 automatic stations from its air quality network: Car (Carapungo), Cot (Cotocollao), Bel (Belisario), Cen (Centro Histórico), Cam (Camal), Gua (Guamani), Tum (valley of Tumbaco), Chi (valley of Los Chillos). Grey zones show the $\mathrm{NO}_{\mathrm{x}}$ emission ( $\mathrm{t} / \mathrm{y}$ ) from on-road traffic during the year 2012 [11]. Dashed lines depict topography (masl). 
On-road traffic is a significant source of air pollutants in the DMQ. According to the emission inventory of the year 2007, this sector contributed with $98 \%$ of $\mathrm{CO}, 54 \%$ of $\mathrm{NO}_{\mathrm{x}}, 46 \%$ of $\mathrm{PM}_{2.5}$ and $40 \%$ of non-methane $\mathrm{VOC}$ [12] of the total emissions in this region. On-road traffic emissions are mainly located in the urban area of Quito, the capital of Ecuador (Fig. 2), which has an average altitude of 2800 masl. Traffic varies between weekdays and weekends, both in timing and magnitude (Figs 3 and 4). The roads with most traffic are located mainly in the north of the urban area of Quito and those that connect to the valleys of Los Chillos and Tumbaco. In the north of Quito, the traffic on weekdays is higher than Saturday (10\%) and Sundays (60\%) flows. In the south, traffic of Saturdays is similar to weekdays. On Sundays, the traffic intensity is reduced by $26 \%$ [13].

Table 1 shows the number of days exceeding the World Health Organization guideline for $\mathrm{O}_{3} 8 \mathrm{~h}$-mean concentration, obtained from the annual air quality reports of the period 2005-2012 [14]. Gua (south of Quito) and Cen (historic center of Quito), with 15 and 10 respectively, are the stations with the highest number of exceedances. In the Cen station, half of the exceedances happened on weekends.

Table 1: Number of days exceeding the World Health Organization guideline for $\mathrm{O}_{3} 8 \mathrm{~h}$-mean concentrations $\left(100 \mu \mathrm{g} / \mathrm{m}^{3}\right)$ during the period 2005 2012.

\begin{tabular}{ccc}
\hline Station & Total exceedances & Exceedances on weekends \\
\hline Car & 1 & 0 \\
Cot & 5 & 3 \\
Bel & 5 & 3 \\
Cen & 10 & 5 \\
Cam & 7 & 3 \\
Gua & 15 & 4 \\
Tum & 2 & 1 \\
Chi & 5 & 3 \\
\hline
\end{tabular}

\section{Method}

We analyzed the hourly records of the period 2005-2012, from 8 automatic stations of the air quality network (Fig. 2). Both for each station and year, 3 meandaily profiles were obtained for $\mathrm{CO}, \mathrm{NO}_{2}, \mathrm{PM}_{2.5}$ and $\mathrm{O}_{3}$, corresponding to weekdays, Saturdays and Sundays. In addition, the $\mathrm{O}_{3} 8$-h mean concentrations were obtained to quantify the percentage of variation of Saturdays and Sundays in relation to weekdays. $\mathrm{O}_{3} 8$-h concentrations were obtained as the mean of the hourly concentrations between $09 \mathrm{~h} 00$ to $16 \mathrm{~h} 00$, considering that during this period typically the $\mathrm{O}_{3}$ concentrations are higher. This approach is the same that Seguel et al. [15] followed in the study of the WE in Santiago, Chile. 


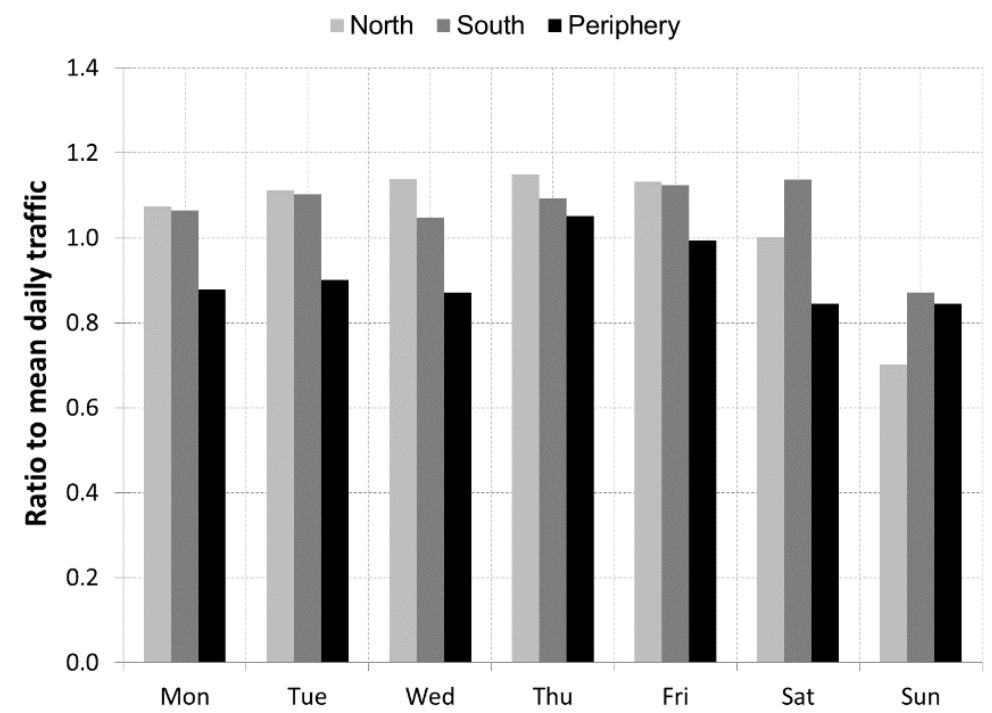

Figure 3: Variation of the traffic flow per day in comparison to the mean daily traffic in the Distrito Metropolitano de Quito. Year 2012 [13].

\section{- -Weekdays -Weekends}

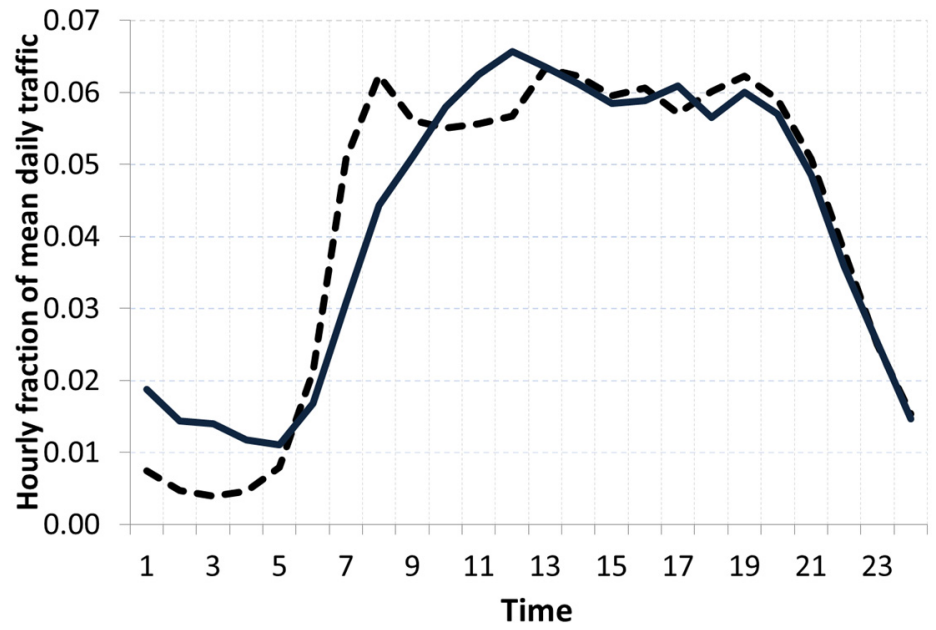

Figure 4: Mean daily profiles of hourly traffic for weekdays and weekends in the Distrito Metropolitano de Quito. Year 2012 [13]. 


\section{Results}

Only the profile patterns obtained for Bel (center-north of the urban area of Quito) and Cen (historic center of Quito) stations are shown, because they are the relevant results for the purpose of this analysis. The mean daily patterns of $\mathrm{CO}, \mathrm{NO}_{2}$ and $\mathrm{PM}_{2.5}$ during the year 2012 declined on Saturdays and Sundays (Figs 5 and 6). The patterns on Saturdays show lower concentrations in comparison to Sundays. However the $\mathrm{O}_{3}$ profiles were higher on Saturdays and Sunday in comparison to weekdays. For the previous years (2005-2011), the patterns show the same configuration.
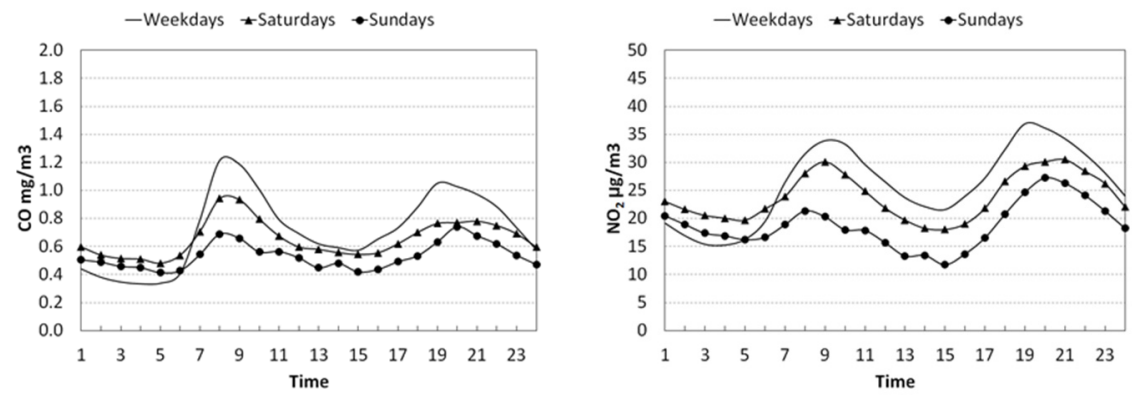

$\mathrm{CO}$

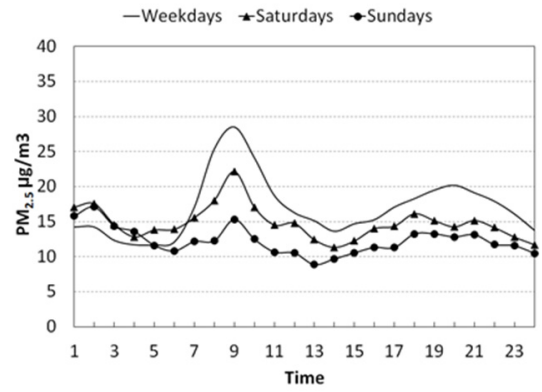

$\mathrm{NO}_{2}$

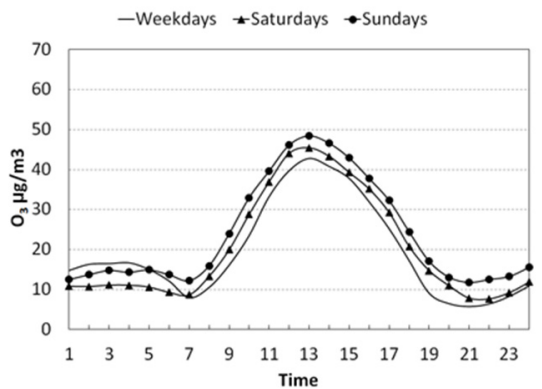

$\mathrm{PM}_{2.5}$

$\mathrm{O}_{3}$

Figure 5: Mean daily patterns of $\mathrm{CO}, \mathrm{NO}_{2}, \mathrm{PM}_{2.5}$ and $\mathrm{O}_{3}$ during the year 2012. Belisario station.

During the period 2005-2012, the percentage of variation of the $\mathrm{O}_{3} 8-\mathrm{h}$ mean concentrations on Saturdays in comparison to weekdays were higher in Bel (5.2$22.7 \%$ ). At the rest of the stations, including Cen, the differences were less than $10 \%$; or even negative as in Gua $(2006,2007,2010,2012)$, Tum (2010) and Cam (2010) stations (Fig. 7).

The percentage of variation of the $\mathrm{O}_{3} 8-\mathrm{h}$ mean concentrations on Sundays in comparison to weekdays was higher in Bel (19.7-31.1\%) and Cen (11.7-18.4\%) (Fig. 8). In the other 6 stations, except for in the years 2009 and 2010, this percentage was less than $10 \%$. 


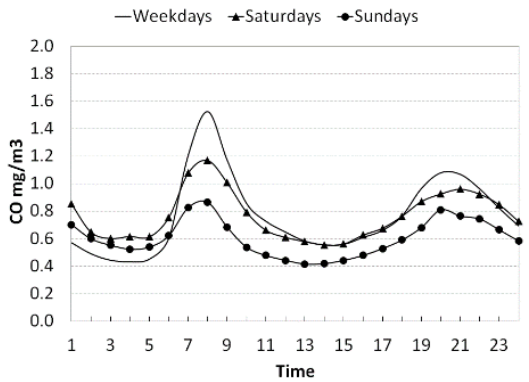

$\mathrm{CO}$

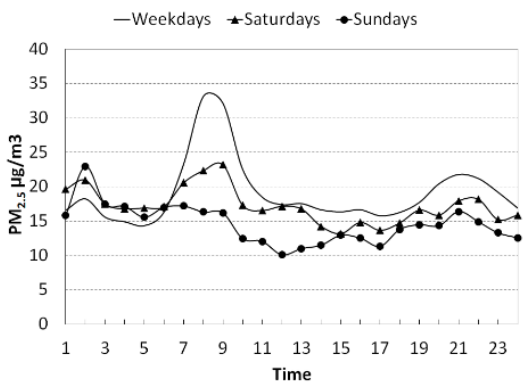

$\mathrm{PM}_{2.5}$

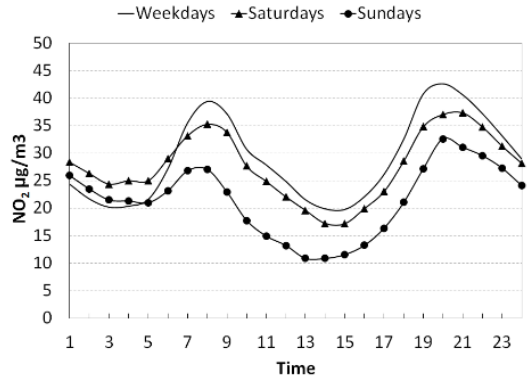

$\mathrm{NO}_{2}$

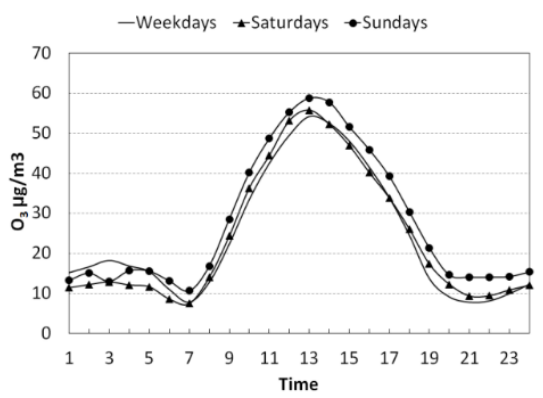

$\mathrm{O}_{3}$

Figure 6: Mean daily patterns of $\mathrm{CO}, \mathrm{NO}_{2}, \mathrm{PM}_{2.5}$ and $\mathrm{O}_{3}$ during the year 2012. Centro station.

\section{Conclusions and discussion}

Results indicate the presence of the WE around the Bel and Cen stations, which was clearly identified for Sundays. The percentages of variation of the $\mathrm{O}_{3} 8-\mathrm{h}$ mean concentrations in Cen (11.7-18.4\%) and Bel (19.7-31.1\%) are consistent with the percentages (18.9-30.1\%) reported by Seguel et al. [15], in the study of the WE in Santiago, Chile. These stations are located in consolidated urban zones, where on-road traffic is the most relevant source of pollutants.

In the Gua station, the WE was not identified. Moreover, during the weekends, 8h-mean $\mathrm{O}_{3}$ concentrations in some years were lower in comparison to weekdays. This station is located in a transitional zone, with features of both non-consolidated urban and rural zones.

In the other stations, the presence of the WE was unclear or was not identified. In the case of the Chi and Tum stations, they are probably located in zones where 
the ratio $\mathrm{VOC} / \mathrm{NO}_{\mathrm{x}}$ corresponds to a $\mathrm{NO}_{\mathrm{x}}$-Limited Regime, owing to $\mathrm{VOC}$ emission from vegetation.

According to the emission inventory of the year 2012, about 520000 vehicles circulated in the DMQ, $94.4 \%$ of which correspond to gasoline vehicles and 5.6\% to diesel vehicles. On-road traffic emitted $102.7 \mathrm{kt} / \mathrm{y}$ of CO, $20.9 \mathrm{kt} / \mathrm{y}$ of $\mathrm{NO}_{\mathrm{x}}$, $13.2 \mathrm{kt} / \mathrm{y}$ of non-methane $\mathrm{VOC}$ and $1.2 \mathrm{kt} / \mathrm{y}$ of $\mathrm{PM}_{2.5}$ [11]. The gasoline vehicles emitted $86.3 \%$ of $\mathrm{CO}$ and $77.0 \%$ of non-methane VOC of the total on-road traffic emissions. The diesel vehicles, although representing only $5.6 \%$ of the park fleet, emitted $82.5 \%$ of $\mathrm{PM}_{2.5}$ and $60.6 \%$ of $\mathrm{NO}_{\mathrm{x}}$ of the total on-road traffic emissions.

Of the diesel fleet, cargo trucks (51\% of the total diesel vehicles), buses (16\%) and vans $(15 \%)$ are the most numerous. These vehicles notably reduce their activity during weekends. Hence, important reductions in $\mathrm{NO}_{\mathrm{x}}$ and $\mathrm{PM}_{2.5}$ emissions happen on weekends.

Of the gasoline park, automobiles ( $74 \%$ of the total gasoline vehicles) and pickups $(14 \%)$ are the most relevant. The lower activity of these vehicles during weekends mainly produces reductions of $\mathrm{CO}$ and non-methane VOC emissions.

The reduction of $\mathrm{CO}, \mathrm{NO}_{\mathrm{x}}$ and $\mathrm{PM}_{2.5}$ emissions during weekends are reflected as lower concentrations of these pollutants in the daily patterns of Figs 5 and 6 . This information suggests that the first hypothesis could explain the presence of the WE around the Bel and Cen stations, which probably are located in a VOCLimited Regime where $\mathrm{NO}_{\mathrm{x}}$ reduction during weekends promotes the formation of $\mathrm{O}_{3}$.

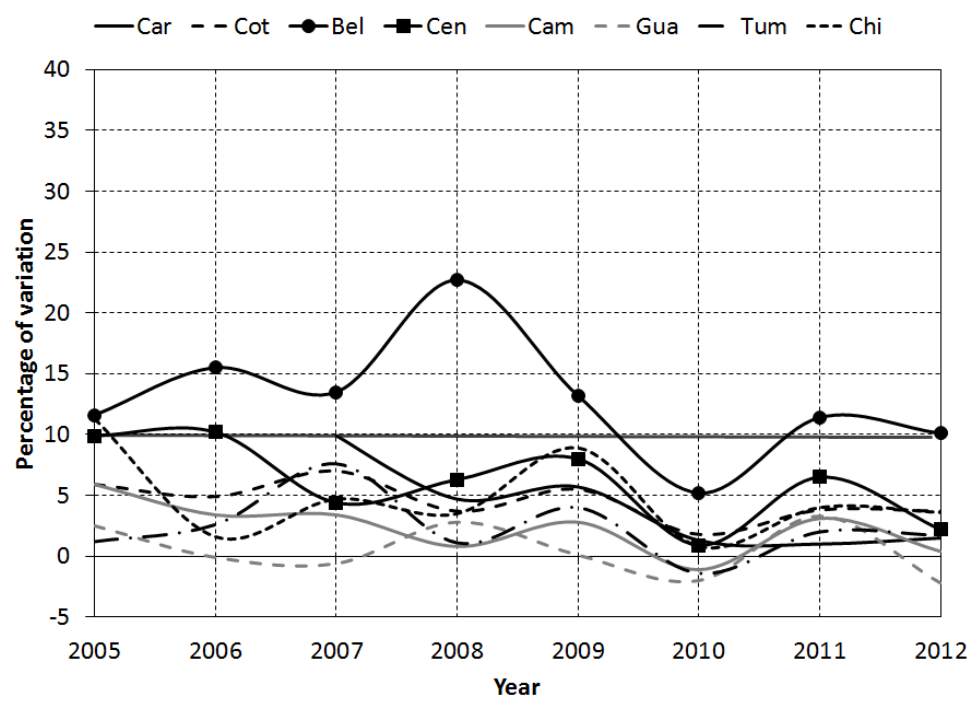

Figure 7: Variation of the $\mathrm{O}_{3} 8$ h-mean concentrations from Saturdays to weekdays. 


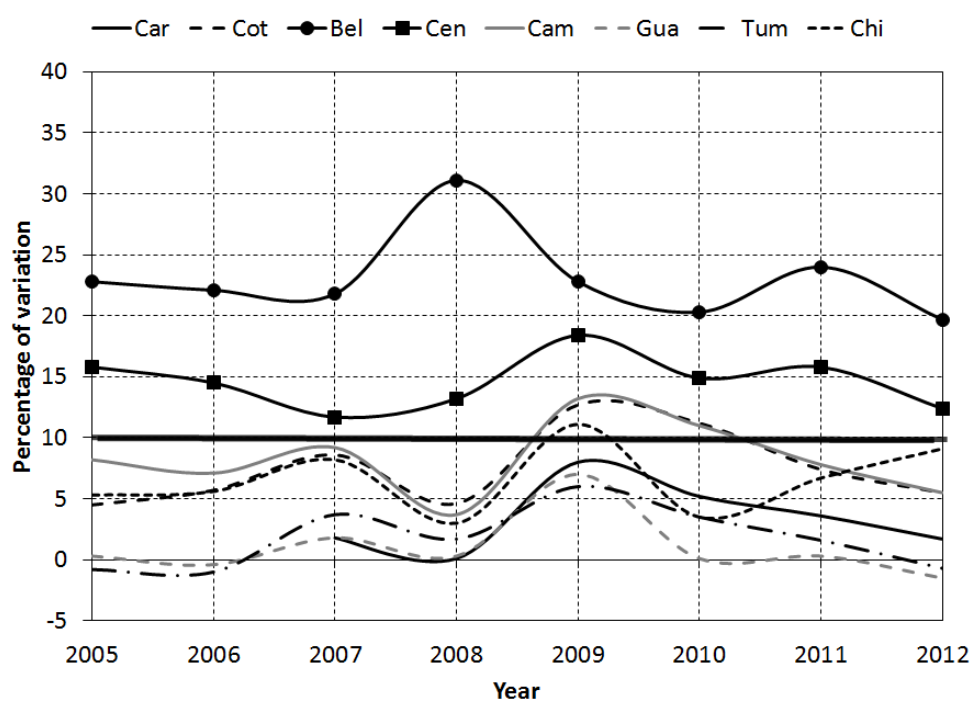

Figure 8: Variation of the $\mathrm{O}_{3}$ 8h-mean concentrations from Sundays to weekdays.

Also, the reduction of $\mathrm{PM}_{2.5}$ concentrations on weekends suggests that the sixth hypothesis of the WE can explain the increase of $\mathrm{O}_{3}$, because the lower concentration of soot and other particles absorbs less UV in comparison to weekdays, allowing more photochemical activity.

Additionally, the second $\left(\mathrm{NO}_{\mathrm{x}}\right.$ timing, associated with delayed $\mathrm{NO}_{\mathrm{x}}$ emissions during the morning of weekends (Fig. 4)) and seventh (surface $\mathrm{O}_{3}$ quenching, associated with less $\mathrm{O}_{3}$ is destroyed on weekends because the reduced $\mathrm{NO}_{\mathrm{x}}$ emissions, Fig. 3) hypotheses could contribute to the WE in Quito.

The participation of the third (carryover near the ground level) and fourth (carryover aloft) hypotheses seems less clear or not relevant for the case of Quito. Finally, we can discard the fifth hypothesis (increased weekend emissions), because no emission sources have been identified in the urban region of Quito, which could permanently contribute with more $\mathrm{NO}_{\mathrm{x}}$ and $\mathrm{VOC}$ emissions on weekends in comparison to weekdays $[12,16]$.

Because the results suggest that the consolidated urban area of Quito corresponds to a VOC-Limited Regime, the $\mathrm{O}_{3}$ production could be controlled by reducing or by controlling the presence of VOC in this area. Preliminary modeling exercises indicated that during midday in the urban area of Quito, wind can travel toward the south, transporting air masses which experiment $\mathrm{O}_{3}$ increments as photochemical reactions happen [17]. This behavior explains the higher number of $\mathrm{O}_{3}$ exceedances at the Gua station, which is located at the south of Quito. Hence, controlling the $\mathrm{O}_{3}$ production in the center of Quito could reduce the exceedances at the south of the city. 
Modeling can be used to quantify the contribution of the WE's hypotheses in the urban area of Quito and hence for assessing the effectiveness of controlling VOC for $\mathrm{O}_{3}$ production. For this purpose, the emission inventory of the DMQ needs to be updated and improved to generate air emission maps with high spatial $\left(1 \mathrm{~km}^{2}\right)$ and temporal resolution $(1 \mathrm{~h})$. These maps must include the changes, both in magnitude and time, of the relevant emission sources of $\mathrm{O}_{3}$ precursors $\left(\mathrm{NO}_{\mathrm{x}}\right.$ and VOC) as on-road traffic, use of solvents, vegetation, service stations, power facilities and industries. These emissions then can be used into a Eulerian chemical transport model.

\section{Acknowledgement}

To Hilary Brumberg, who checked this paper.

\section{References}

[1] Jacobson, M., Atmospheric Pollution. History, science and regulation. Cambridge University Press, New York, 656 p., 2002.

[2] CARB, The ozone weekend effect in California. Staff Report, The Planning and Technical Support Division, The Research Division, Air Resources Board, California Environmental Protection Agency, 2003.

[3] NRC, Ozone-Forming Potential of Reformulated Gasoline. National Academic Press, Washington D.C., 1999.

[4] NARSTO, An Assessment of Tropospheric Ozone Pollution - A North American Perspective. NARSTO Management Office (Envair), Pasco, Washington, 2000.

[5] Cleveland, W.S., Graedel, T.E., Kleiner, B., Warner, J.L., Sunday and workday variations in photochemical air pollutants in New Jersey and New York. Science, 186, 1037-1038, 1974.

[6] Lebron, F., A comparison of weekend-weekday ozone and hydrocarbon concentrations in the Baltimore-Washington metropolitan area. Atmospheric Environment, 9, 861-863, 1975.

[7] Altshuler, S.L., Arcado, T.D., Lawson, D.R., Weekday vs. weekend ambient ozone concentrations: discussion and hypotheses with focus on Northern California. Journal of the Air \& Waste Management Association, 45, 967-972, 1995.

[8] Brönnimann, S., Neu, U., 1997, Weekend-weekday differences of nearsurface ozone concentrations in Switzerland for different meteorological conditions. Atmospheric Environment, 31, 1127-1135, 1997.

[9] Qin, Y, Tonnesen, G.S., Wang, Z., One-hour and eight-hour average ozone in the California South Coast Air Basin: trends in peaks values and sensitivity to precursors. Atmospheric Environment, 38, 2197-2207, 2004.

[10] Jiménez, P., Parra, R., Gassó, S., Baldasano, J.M., Modeling the ozone weekend effect in very complex terrains: a case study in the Northeastern Iberian Peninsula. Atmospheric Environment, 39, 429-444, 2005. 
[11] Vega, D., Ocaña, L., Parra, R., Inventario de emisiones atmosféricas del tráfico vehicular en el Distrito Metropolitano de Quito Año base 2012, Avances en Ciencias e Ingeniería, Vol. 7, No. 2, C82-C90, 2015.

[12] CORPAIRE, Inventario de Emisiones del Distrito Metropolitano de Quito Año 2007, Corporación Municipal para el Mejoramiento del Aire de Quito, 2009.

[13] Vega, D., Parra, R., Caracterización de la intensidad media diaria y de los perfiles horarios del tráfico vehicular del Distrito Metropolitano de Quito, Avances en Ciencias e Ingeniería, Vol. 6, No. 2 C40-C45, 2014.

[14] Secretaría de Ambiente, Municipio del Distrito Metropolitano de Quito, http://www.quitoambiente.gob.ec/

[15] Seguel, R., Morales, S., Leiva, M., Ozone weekend effect in Santiago, Chile, Environmental Pollution, 162, 72-79, 2012.

[16] CORPAIRE, Inventario de Emisiones del Distrito Metropolitano de Quito Año 2005, Corporación Municipal para el Mejoramiento del Aire de Quito, 2008.

[17] Parra, R., Pérez, C., Estrategia para el desarrollo de un modelo de predicción de la calidad del aire de Quito y resultados preliminares de la fase de diagnóstico, Acta Nova, 3, 2, 238-256, 2006. 